\title{
Internal Relationship Marketing and Job Performance: A Theoretical Analysis
}

\author{
Meryem El Alaoui Amine ${ }^{1}$, Laila Ouhna ${ }^{2}$ \\ ${ }^{1}$ Faculty of Juridical, Economic and Social Sciences Salé, University Mohammed V, Rabat, Morocco \\ ${ }^{2}$ Faculty of Juridical, Economic and Social Sciences, Ait Melloul, Ibn Zohr University, Agadir, Morocco \\ Correspondence: Meryem El Alaoui Amine, Faculty of Juridical Economic and Social Sciences- Salé, University \\ Mohammed V - Rabat, Morocco. Avenue des Nations Unies B.P:8007, Agdal -Rabat, Morocco.
}

Received: August 27, 2018

Accepted: September 25, 2018

Online Published: October 23, 2018

doi:10.5539/ibr.v11n11p128

URL: https://doi.org/10.5539/ibr.v11n11p128

\begin{abstract}
Human resources are considered as one of the important intangible resources of company composed mainly of employees' knowledge, skills and attitudes. When human capital is scarce, precious and difficult to imitate, it can be a source of sustainable competitive advantage. Internal Relationship Marketing (IRM) acts in this sense. It is considered as a process of creating, developing and maintaining sustainable relationships between the company and its employees. In this context, and through an analysis of the existing literature in this field, we will try to study the effects of IRM on the employee job performance. The main results of this work are that the IRM, through its relational determinants namely: communication, organizational trust, organizational commitment and job satisfaction, help improve employee job performance and more precisely task performance and contextual performance. This study wraps up by a proposal of a conceptual model, linking the different components of our research.
\end{abstract}

Keywords: internal relationship marketing, job performance, communication, trust, commitment, satisfaction, task performance, contextual performance

\section{Introduction}

In a constantly changing economic environment, marked by fierce competition and increasingly sophisticated customer requirements, companies seek to create and maintain sustainable competitive advantages. Human resources are one of the competitive advantages, as they are rare, valuable and difficult to imitate (Javadein et al. 2011). Relationship marketing intervenes in this sense. It aims to establish, develop and maintain sustainable and successful exchange relationships with internal and external partners of the company. It marks the reference of companies to a relational and defensive orientation rather than a transactional and offensive orientation. Relationship marketing is applied in all relationships between the company and its various stakeholders. Regarding the organization-employee relationship, internal marketing is used as a specific tool for managing this type of relationship (Morgan and Hunt, 1994).

Various theoretical and empirical studies have shown that the relationship marketing has positive effects on financial and organizational performance of the company (Jang et al.2006, Leo et al. 2002). However, few studies have examined the effects of adopting a relationship marketing approach at the internal level of the company on employee job performance. This paper aims to fill this gap. Our goal is to know how internal relational marketing influences employee job performance.

In this context, we will try to provide theoretical answers to this major issue, based on existing literature reviews in this area. In the first place, we will try to highlight the role of IRM in managing the relationships between the company and its employees. In a second place, we will focus on job performance and its components. Finally, we will try to establish links between IRM and employee job performance as well as to propose a conceptual model representing the different links.

\section{Internal Relationship Marketing}

From the definition of internal marketing (1-1) and the distinction between its transactional and relational tools (1-2) necessary for its implementation, we will emphasize the role of Internal Relationship Marketing in the management of relations between the company and its employees (1-3). 


\subsection{Definition of Internal Marketing (IM)}

The concept of IM finds its origins in the work of Sasser and Arbeit (1976) who considered that employees are the first market of the company. Berry (1984, p : 272) stressed that IM is "considering the employee as an internal consumer, working as an internal product and meeting the needs and desires of internal clients while meeting the organization's goals." Similarly, Berry \& Parasuraman (1991, p: 151) defined IM as "attracting, training, motivation and retention of qualified employees through job products that meet their needs. The IM is the philosophy of treating as clients (...). This is the strategy of shaping the work to fit human needs. "

The literature proposes several definitions of internal marketing. However, these definitions can be grouped into five main components (Shiu \& Yu, 2010):

- The employee is considered an internal consumer: Gronroos (1981) is the first author to define IM as a means to see the employee as an internal consumer. Several authors have supported his point of view in particular: Cahill (1996a, 1996 b), Lings (2004). The goal of this vision is to foster employee satisfaction which in turn leads to improved business performance (Shiu and Yu, 2010) .

- Employee and customer orientation: In this component, the objective of IM is to stimulate employees to develop behaviors favoring the customer orientation of the companies through the implementation of a set of marketing programs for the internal market, similar to those of the external market. Moreover, using approaches, theories, concepts, tools and techniques of marketing, IM contributes to employee motivation (Papasolomou, 2006), and satisfaction of internal customers of the company namely employees.

- Management orientation of Human Resources: According to Cooper \& Cronin (2000), the goal of IM is to train, encourage and motivate employees to provide better service. This idea is supported by several studies (Berry \& Parasuraman, 1991; Joseph, 1996; Rafiq \& Ahmed 2000 ; Kelemen and Papasolomou-Doukakis 2004 ; Zboja et Hartline, 2010) which demonstrate that IM should be used in human resources management and marketing to stimulate, encourage, mobilize, recruit and manage all employees within an organization and improve the methods of offering service to external and internal customers (Shiu and Yu, 2010) .

- Internal exchange: Some research (Lings et Greenley 2009; Shiu \& Yu 2010) has justified the importance of IM by the fact that to satisfy external customers, it is first necessary to take care of the internal exchange, i.e the exchange between a company and its employees.

- Strategic tool: According to Dennis (1995), IM is a philosophy, a managerial strategy consisting of attracting, developing, motivating and retaining employees by providing the necessary elements to satisfy employees in the job.

Ahmed and Rafiq (2000, 2003, 2004) proposed a more comprehensive definition of IM: « internal marketing as a planned effort using a marketing like approach to overcome organizational resistance to change and to align, motivate and inter-functionally coordinate and integrate employees towards the effective implementation of corporate and functional strategies in order to deliver customer satisfaction through a process of creating motivated and customer-oriented employees".

\subsection{From Internal Marketing Based on Transactional Marketing to Internal Relationship Marketing}

The definition of IM highlights the use of transactional marketing techniques and tools in motivating and satisfying employees in the workplace. Ahmed and Rafiq (1995) emphasized that the IM is based on marketing techniques such as marketing mix with 4Ps (Price, Product, Promotion, Place), segmentation, market research ... Concerning the application of the marketing mix to internal marketing, Ahmed and Rafiq (1995) argue that, given the intangibility of the product marketed (i.e the idea: "the employee is considered an internal consumer" and " awareness by employees of the importance of customer orientation"), it was proposed to add two concepts " Process" and "Participants" to the 4Ps of traditional marketing, in order to ensure inter-functional interdependence necessary for the production of an excellent service. More specifically, the application of marketing mix to IM can be translated as follows:

- Product: Corresponds to work (Flipo, 2000; Berry and Parasuraman 1991).

- Price: Refers to the psychological cost of adopting new working methods.

- Communication-Promotion: Motivating employees and influencing their attitudes and behaviors are important aspects of IM that require the adoption of communication strategies. More specifically, the effectiveness of communication with employees depends on the coordination between different media and communication techniques with employees. 
- Place: it refers to the location and channels (or third party) that is used to deliver products to customers. In internal marketing, distribution refers to conferences, meetings, trainings, in which new policies and procedures are announced.

- Processes: These are the processes used in the IM to motivate and satisfy employees in the workplace to ensure client satisfaction and excellence in service offerings. These include the introduction of quality circles, reporting methods ...

- Participants: These are the people involved in the production and delivery of the product and those who receive the product and who can influence the customer's perception; especially the employees and managers of the company.

Internal marketing also uses the relational approach for its implementation. Morgan and Hunt (1994) counted ten forms of relationship marketing based on exchange relations between the company and its partners, among others, the exchange relations between the company and its employees through the internal marketing. Dwyer et al. (1987) consider the relationship marketing as "all marketing activities aimed at the establishment, development and maintenance of trade relations." The exchange relations must not be limited to a relationship between the company and the customer but rather to a relationship between the company and all its where the objectives of both parties meet (Sin et a1., 2005).

Relationship marketing has a process character (Gronroos, 2004). Palmatier (2008) considers the relationship marketing as "the process of identifying, developing, and maintaining relational exchanges in order to improve performance." So the goal of the companies behind adopting a relationship marketing approach is improving performance.

In this paper, we adopt relationship marketing as an approach to analysis the exchange relationships between employee and company. In this perspective, the implementation of tools and techniques of relationship marketing in internal marketing allows us to well study the concept of Internal Relationship Marketing and to distinguish it from internal marketing based on transactional marketing. To this end, we will name the articulation between relationship marketing and internal marketing, "Internal Relationship Marketing" (IRM) and this in order to distinguish it from internal marketing based on transactional marketing.

\subsection{Internal Relationship Marketing as a Process of Managing the Exchange Relationships Between Employee and Company}

According to berry (1983), internal marketing involves using marketing techniques inside the organization in order to satisfy the employee. It aims to consider the employee as internal consumers and work as a product. Javadein et al., (2011), indicates in this sense, that employee satisfaction is very beneficial for the organization, particularly in terms of quality service offerings and the creation and the retention of a sustainable competitive advantage. IM is seen as "a relationship development process in which staff autonomy and know-how combine to create and circulate new organizational knowledge that will challenge internal activities which need to be changed to enhance quality in market place relationships" (Ballantyne, 1997: 354). In this way, the IM aims to create a motivating work environment that fosters employee cooperation, creativity and innovation. Such a climate affects the actions and behaviors of employees that are likely to influence directly or indirectly customer satisfaction.

Thus, Gounaris (2010) indicated that the organization can satisfy its external customers, by the satisfaction of its internal customers. Employees are a valuable resource for the company to ensure its competitive advantage. For these reasons, companies are encouraged to strengthen their relationships with employees through high-level partnership contracts that will ensure effective relationships between employees themselves, and between different departments and functions of the company.

In this context, several questions may be raised: how can firms develop effective processes for structuring and managing internal relationships? What is the nature of the partnership between the company and the employees? What tools and mechanisms are needed for its implementation? The works of Ahmed and Rafiq $(2002,2003)$ provides answers to these questions. These answers can be divided into two parts: firstly, relational marketing is, according to the authors, an adequate theoretical framework for studying these problems. In fact, the relational approach presents an alternative framework to the transactional approach of marketing which formed the basis of the thinking of internal marketing. Secondly, internal marketing contributes to the achievement of high-level partnership contracts through three tools: understanding, trust and commitment (Ahmed and Rafiq, 2003). These mechanisms participate in the establishment, the development and the maintenance of a successful exchange relationship within the organization. 
Theron and Terblanche (2010) announced the presence of four core values in the relationship marketing literature: commitment, trust, satisfaction and communication. They constitute the relational determinants of internal relationship marketing (El Alaoui Amine et al., 2012, EL Alaoui Amine et al., 2013).

The construct trust-commitment has been the subject of several works in relationship marketing literature. In fact, Blois (2003) considers commitment and trust as the distinctive characteristics of a relationship. Sheth (2000, p: 619) argues that "commitment and trust have emerged as blocks for the construction of a theory. The relational theory commitment- trust of Morgan and Hunt (1994) has been particularly influential. Their model "Key Mediating Variables" (KMV) is an important contribution to understanding relationship marketing".

Organizational trust is seen as a "behavioral intent manifested in the willingness to be vulnerable to the exchange partner" Mayer et al. (1995: 712). Organizational trust plays an important role in strengthening employment relationship (Dirks and Ferrin, 2001). It is a determinant of employment relationship quality. Whitener (1998: 393) indicates that "employees can develop a relationship of trust with at least two referents, including supervisor and general representatives of the organization". thus, the type of trust depends on the referent chosen.

Organizational Commitment is described by Meyer and Allen (1991) as "a psychological state that characterizes the relationship between employee and organization, and that has implications for the decision to remain within the organization". The authors distinguished between three forms of engagement: Continuance commitment, affective commitment and normative commitment.

1. Continuance commitment which refers to an awareness of the costs associated with leaving the organization

2. Affective commitment which refers to the employee's identification or strong emotional attachment and involvement in the organization;

3. Normative commitment which reflects an obligation to continue belonging to the organization.

Communication is defined as "the provision of relevant and timely information among actors" (Anderson and Narus ,1990). It is considered as one of the fundamental elements of internal relationship marketing, since it creates a favorable working climate marked by the sharing and the dissemination of information between the company and its employees. Several research have proven the relationship between communication, trust and commitment ( Morgan and Hunt, 1994 ; Caceres and Paparoidamis,2007 ; Zeffane et al. ,2011). According to Morgan and Hunt, (1994) communication is one of the important antecedents of trust-commitment relationship. More precisely, communication directly influences trust and indirectly commitment through trust. In this sense, Zeffane et al. (2011) have argued that employee commitment and loyalty is formed through organizational trust.

Given that IRM aims to satisfy customers through employee satisfaction, the establishment of a climate of trust within the company contributes to increase job satisfaction. Locke defined job satisfaction as "a pleasant or positive emotional state resulting from an individual's assessment of his or her work or work experience" Locke (1976, p. 1300). Empirical studies have shown that job satisfaction is directly and significantly related to organizational trust (Ahmadi et al., 2011, Meral, et al., 2016). Specifically, trust is an antecedent of job satisfaction (Mulki et al., 2006). Also, satisfied employees develop cognitive links with the organization (commitment) and have less intention to leave a company (Iverson and Maguire, 2000). In this sense, Dirania and Kuchinke, (2011) have shown that job satisfaction is a very good preacher of organizational commitment.

To this end, IRM is a process of managing the exchange relations between employees and company. This process is composed of a causal chain starting with communication, then organizational trust, organizational commitment and finally job satisfaction (El Alaoui Amine et al., 2012, El Alaoui Amine et al., 2014). The different components of this chain represent relational determinants that ensure the success of relationship between the company and its employees.

The goal of companies behind the adoption of the IRM is to improve the overall performance of the company and particularly employee job performance.

\section{Job Performance}

The concept of job performance has long suffered from insufficient conceptualization. In fact, most academic work has focused on the study of performance evaluation criteria and techniques, as well as on its individual determinants (motivation, involvement, satisfaction, etc.), but have shown little interest in the definition and the conceptual status underlying the construct (Charbonnier et al., 2007). Since the 1990s, works have been carried out on job performance (Campbell, 1990 ; Borman \& Motowidlo, 1993 ; Rotundo, Sackett, 2002). Campbell (1990) suggests defining job performance as "a set of behaviors or actions that are relevant to the objectives of 
an organization" (1999: 402). Similarly, Motowildo presents a definition that represents a significant advance: " job performance is defined as the total expected value to the organization of the discrete behavioral episodes that an individual carries out over a standard period of time" Motowildo (2003, p: 39). According to Charles-Pauvers et al. (2007), this definition has several indications. Firstly, individual performance refers to behaviors that the organization estimates and expects from its employees. These behaviors positively influence the achievement of organizational objectives (productivity, creativity, profitability, growth, quality, customer satisfaction) and what the individual deploys over different periods of time. Secondly, these definitions favor the distinction between the individual's behaviors beneficial to the organization (performance) and the expected results of these behaviors (effectiveness). However, if we evaluate only the results of an individual, we risk ignoring the situational factors that help or hinder the realization of work by the employee (availability and quality of equipment and resources, strategic and operational decisions beyond the control of a person, market context) (Charbonnier et al., 2007).

Job performance is seen as a multidimensional concept, since it is composed of several categories of homogeneous or similar behaviors that facilitate or hinder the achievement of organizational goals (Charles-Pauvers 2006, 2007, Charbonnier et al., 2007). In this context, since the 90s, several studies have attempted to provide multi-factor models to determine the behavioral properties of the job performance. However, two models have been widely used. These are the multi-factorial model of Campbell (1990) and the job performance model of Borman and Motowildo (1993). First, Campbell's multi-factorial model (1990) identifies eight behavioral dimensions of job performance. These are: 1 / skills in job-specific tasks; 2 / skills in non-specific tasks; 3 / written and oral communication; 4 / efforts in activity; 5 / maintenance of a personal discipline; 6 / contribution to the performance of the team and colleagues 7 / supervision 8 / management and administration. According to Charbonnier et al., (2007), this classification seems to be operational for the establishment of employee assessment procedures, as it is fairly general and flexible in order to be adapted to the different categories of jobs in a company. They highlight, on the one hand, the psychological links between the individual, his work and his organization, and on the other hand the individual skills during the exchange relationship.

Second, the job performance model of Borman and Motowildo (1993) distinguishes between task performance and contextual performance. This distinction has been used by several empirical studies that supported the model of Borman and Motowildo (1993) (Van Scotter and Motowidlo 1996, Johnson et al., 2009, Dalal et al., 2009, Rich et al., 2010, Ahn et al, 2018).

Task performance covers prescribed behaviors, i.e a set of work activities that are traditionally described in the classifications and / or job and skills references. Technical or task performance refers to what Borman and Motowildo, (1993) call "the technical core" of an organization or a job. It concerns the execution of tasks and activities that contribute directly or indirectly to the transformation of resources into products for economic exchange (Borman and Motowildo, 1993). Technical or task activities vary considerably from one job to another and include two types of activities: firstly, transformation of raw materials into goods and services produced by an organization (for example: sales, machine operation, education, etc..). Secondly, activities that support the technical core such as procurement, planning, coordination, maintenance ... This means that tasks are directly linked to the technical core or indirectly by supporting execution of a technique (Motowidlo \& Van Scotter, 1996; Poropat, 2002). These activities are most often concerned with research and business practices in performance appraisal.

Task Performance depends on knowledge skills, abilities, motivations and other related factors involved in performing prescribed tasks (Ang et al., 2007).

Contextual performance is an enlargement of performance evaluation beyond a task performed by an employee (Rotundo, \& Sackett, 2002). This is behavior of individuals involved in organization effectiveness through their effects on psychological, social and organizational context of work. Coleman and Borman (2000) qualify contextual performance as a citizen performance that supports the global environment in which the technical heart can function. Motowidlo (2000) conceptually studied "contextual performance" and "Organizational Citizenship Behaviors" (OCB). They refer to " behaviors of an individual who is left to his or her free choice, not directly or explicitly recognized by formal reward system, and which, as a whole, promotes the efficient and effective functioning of the organization" (Organ 1988, P: 4). It was introduced in the literature prior to the concept of contextual performance by Organ and colleagues (Bateman \& Organ, 1983). However, Motowidlo (2000) reported that both concepts have a similar behavioral content, so much so that the author wondered whether the two labels are really necessary for similar areas of behaviors. The behavioral content of OCBs is multidimensional. It is composed of five elements (Organ ,1988; Organ et al., 2006): altruism, 
conscientiousness, civic virtue, courtesy, sportsmanship.

Williams \& Anderson (1991) clustered the five components of OCBs in two categories of behaviors depending on the beneficiary. These are Organizational Citizenship Behaviors oriented individual (OCBi) and Organizational Citizenship Behaviors oriented organization (OCBo).

Thus, the distinction between task performance and contextual performance allows pinpointing and properly framing the employee job performance. On the one hand, task performance is explained by employee's ability and experience, whereas contextual performance is predicted by personality measures. On the other hand, task performance refers to organizational effectiveness, while contextual performance promotes the efficient functioning of the organization. That is why the evaluation of job performance through the combination of contextual and task performance is important especially in the services sector where the performance of employees depends on their qualifications and skills in the work, but also on OCBs that contribute to a better service offer.

\section{Contribution of Internal Relationship Marketing to Job Performance}

Ivens and Mayrhofer (2003) indicated that among the success factors of relationship marketing are: hardware and software. Hardware constituted by structures and instruments presenting the content of actions carried out. Software based on relational principles that govern behaviors of a company towards its stakeholders and especially employees.

The effectiveness of relationship marketing contributes to increase company's overall performance (Ismail, 2009, Ismail and Alsadi, 2010) specifically employee job performance (Lings et al. 2009) Moreover, IRM affects employees' attitudes and behaviors that have a direct impact on employee performance (Saknarong et al., 2013, Mohiuddin Babu, 2017).

IRM is seen as a tool for realizing company's internal orientation (Hales 1994, Varey and Barbara 1999, Carter and Gray, 2007, Abbas and Riaz, 2018). This orientation is based on exchange principles between employees and organization. Internal exchange is examined in human resources literature in terms of equity theory (Adams, 1963) whereby employees evaluate their jobs by comparing their inputs and outputs. Carter and Gray (2007) report that inputs are related to effort, loyalty to the organization and compliance with organizational policy. The outputs include compensation, benefits and intangible rewards such as status, recognition of work well done and the feeling of accomplishment. For a company, the offer of employment and working conditions are products that will be marketed to employees under a contract of employment. However, in this contract of employment, the employer is both buyer and consumer, which makes it difficult to manage employee-organization relationship (Hales 1994). From this perspective, Carter and Gray (2007) underscore that employees are forced to adapt their individual goals to those of the organization. On the other hand, the company through its managers must make sound decisions that meet company's needs and employee's expectations. Literature in human resources management and marketing suggests that managers must carefully balance and gauge the inputs and outputs to maximize employee performance (Freedman and Montanari 1980; Guest and Conway 2002). All compensation and benefits decisions have a direct impact on employee attitudes and behaviors, as well as their job performance and, therefore, organizational effectiveness and efficiency over the long term (Carter et al. Gray, 2007).

Keller et al. (2006) indicates that the introduction of IRM in a company has a positive effect on employee attitudes to their work and to an organization, as it promotes developing employee emotional attachment to a company. Saknarong et al. (2013) adds that IRM influences employee attitudes and behaviors to improve job performance. More specifically, IRM contributes to increase organizational commitment and employee satisfaction, as well as OCB (Carter and Gray, 2007, Shiu and Yu, 2010, Saknarong, 2013, Abbas and Riaz, 2018).

At the empirical level, several studies have tried to verify the existence of links between IRM and employee job performance. Cano and Sams (2009) studied the role of emotions in the success of social services. The results suggest that emotional intelligence mediates relationship between emotion in work and stress in work which in turn has positive effects on job performance. The authors indicated that adoption of an IRM approach is necessary to better match the organization's products (i.e. work) to internal clients (i.e employees), and hence, improving offer quality to external customers (job performance). Also, Chen \& Liu (2012) analyzed the relationship between IRM, organizational commitment, participation in work, job satisfaction and job performance of elderly care facilities employees in Taiwan. They found that 1 / IRM positively affects organizational commitment and participation in work, 2 / job performance is positively influenced by participation in work, job satisfaction and IRM. Saknarong et al. (2013) argues that IRM contributes to increased employee job performance and service excellence through creating organizational commitment and employee job satisfaction. 
Previous research has shown that IRM has a positive impact on task performance. This is the case, for example, of Yao et al. (2013) who studied, with 617 employees of petrochemical companies, how IRM can influence empowerment and employee job performance, specifically tasks performance. They found that companies use IRM as an effective way to improve a level of psychological employee empowerment and thereby increase employee tasks performance.

Some studies have focused on the impact of IRM on specific components of employee job performance including (OCB) and task performance (Borman and Motowidlo, 1993). Chang et al. (2012) identified the existence of a positive effect of IRM on OCB. These results are in line with research findings of Yoon \& Suh (2003). Organ et al. (2006) points out that OCBs carried out by employees play a crucial role in promoting organizational performance. Moreover, OCBs contribute to reducing business costs, conserving resources and improving staff cooperation.

\section{Conceptual Model Proposal}

The adoption of an IRM approach within the company encourages the improvement of employee job performance (Mishra, 2010; Yao et al., 2013). Indeed, effective communication between company and employees, and among employees themselves, promotes a climate of organizational trust and therefore development of organizational commitment and job satisfaction (El Alaoui Amine et al., 2012). These attitudes and behaviors contribute to increase employee job performance.

However, as mentioned earlier, IRM and employee job performance are multidimensional constructs. The first is composed of four variables (communication, organizational trust, organizational commitment and job satisfaction) while the second is made up of two variables (task performance and OCB). In the following, we will try to study the links between each variable of IRM and those of job performance.

\subsection{Communication and Performance at Work}

Previous research has shown that communication within a company promotes increased employee job performance (Ang et al., (2007), Yildirim, 2014). Berry and Parasuraman (1991) consider that internal communication consists of various key aspects without which the necessary quality to empower the organization's personel to deliver sound performances wouldn't exist (Roșca ,2017). we propose:

\section{Proposition 1: Communication positively influences employee job performance.}

Communication helps improve individual tasks performance (Zhang \& Huai, 2016). In fact, tasks are usually indicated in formal job responsibilities. However, task execution requires employee mastery of skills, knowledge and attitudes (Ang et al., 2007). Cross and Cummings, (2004) reported that good communication between the company and its employees helps to solve business problems by accessing quickly to the right person. Also, "communication is a means through which the task and the resources needed to carry out an assignment, the roles and duties and the expected results are made known to the subordinates which makes work easier for better performance. Managers need to communicate with employees regularly to get feedback and offer suggestions in other to prevent confusion about future job assignments; this will help improve workers performance and organizational productivity" (Femi, 2014, p: 80). Thus, we propose the following:

Proposition 1-1: Communication positively influences task performance.

Communication also contributes to the development of OCBs. Yildirim, (2014) empirically verified, in textile sector, the impact of organizational communication on OCBs. The author concludes that effective organizational communication is not only important for setting up channels between managers and employees but also necessary to implicitly contribute to the overall performance of the organization through OCBs.

\section{Proposition 1-2: Communication positively influences Organizational Citizenship Behaviors.}

\subsection{Organizational Trust and Job Performance}

The development of communication links also allows a group of employees in a company to create a favorable working climate. This climate is motivating to collaborate with other employees and superiors and encourage organizational trust relationships. Thus, the entailing positive environment supports job performance. Also, trust in face-to-face teams has been determined to have a direct positive influence on performance ( Coovert et al. ,2017), and organizational citizenship behaviors (Dirks and Ferrin 2001). These results have been supported at both the individual (Costa 2003) and team (De Jong and Elfring 2010; Coovert et al. (2017)) levels. The following hypothesis is proposed :

Proposition 2: Organizational trust positively influences job performance. 
The establishment of an organizational trust climate encourages development of task performance (Zhang \& Huai, 2016). Many researchers have shown that organizational trust is an antecedent of task performance (Dirks \& Ferrin, 2002, Colquitt et al., 2007).

\section{Proposition 2-1: Organizational trust positively influences task performance.}

Dirks \& Ferrin (2002) argue, on the basis of a meta-analysis, that organizational trust and particularly trust in leaderships positively influence OCBs. This result is supported by the research of Singh \& Srivastava's (2016) who investigated the impact of several organizational factors (perceived organizational support, procedural justice, and communication) as determinants of organizational trust, and their impact on OCB. They found that the presence of organizational trust is positively associated with all dimensions of OCBs. The authors recommend that organizations should facilitate process leading to organizational trust, so that employees will be better engaged in extra-role behaviors (OCB) resulting in increased individual and organizational effectiveness.

\section{Proposition 2-2: Organizational trust positively influences organizational citizenship behaviors.}

\subsection{Organizational Commitment and Job Performance}

Empirical studies have shown a positive and significant relationship between organizational commitment and job performance (Darolia et al., 2010, Jamal, 2011, Fu Deshpande, 2014). Indeed, the relationship between organizational commitment and job performance is positive and stronger for sales employees than for non-sales employees. Stronger correlations between organizational commitment and job performance were also found for collectivist compared to individualistic cultures (Jaramillo et al. 2005).

\section{Proposition 3: Organizational commitment positively influences job performance.}

Employees who are highly committed in their work and in carrying out tasks not only focus their physical effort on pursuing task-related goals, but are also cognitively vigilant and emotionally connected to work. These employees achieve a better performance in job (Felfe et al. 2008, Rich et al. 2010). we propose:

\section{Proposition 3-1: Organizational commitment positively influences task performance.}

On the other hand, committed employees have a stronger tendency to conduct beneficial behaviors that may go beyond the formal tasks or expectations of an organization (Wang and Wong, 2011). In addition, compared with less committed employees, highly committed employees are more likely to contribute to their organization with positive behaviors and to help organization development (Greenfield et al., 2008). This means that organizational commitment is an important antecedent of OCBs (Barzoki \& Ghujali, 2013).

Recently, Bakhit Al Zefeiti and Azmi Mohamad (2017) studied the influence of organizational commitment on work performance in the context of Omani governmental organizations. The empirical results indicate that all organizational commitment subscales (affective, normative, and continuance) have a significant impact on work performance dimensions, contextual and task performance. Therefore, we propose the following:

\section{Proposal 3-2: Organizational commitment positively influences Organizational Citizenship Behaviors.}

\subsection{Job Satisfaction and Job performance}

Research on relationship between job satisfaction and job performance has been conducted since 1940s (Brody, 1945). In fact, the idea that job satisfaction leads to better performance is supported by Vroom's (1964) work which is based on the idea that performance is a natural product of meeting the needs of employees. Many organizational theories are based on the idea that organizations that are able to make their employees happy will have more productive employees (Davar \& RanjuBala, 2012).

\section{Proposition 4: Job satisfaction positively influences job performance.}

Although the various facets of tasks are generally prescribed in employment competency framework, addressed to any employee (satisfied or unsatisfied in his / her work), a satisfied employee will tend to perform his/ her tasks timely and with efficient and effective manner, compared to an unsatisfied employee.

\section{Proposition 4-1: Job satisfaction positively influences task performance.}

However, based on the theory of social exchange, assuming that individuals seek to balance what they give and receive in a social exchange, a satisfied employee will be more likely to help others and develop voluntary behaviors and OCBs compared to an unsatisfied employee (Hee Yoon and Suh, 2003, Edwards et al 2008, Barzoki \& Ghujali, 2013).

\section{Proposition 4-2: Job satisfaction positively influences organizational citizenship behaviors.}

Based on the review of the literature developed throughout this work and the four research proposals presented 
above, we have established a conceptual model linking internal relationship marketing to job performance (Figure 1).

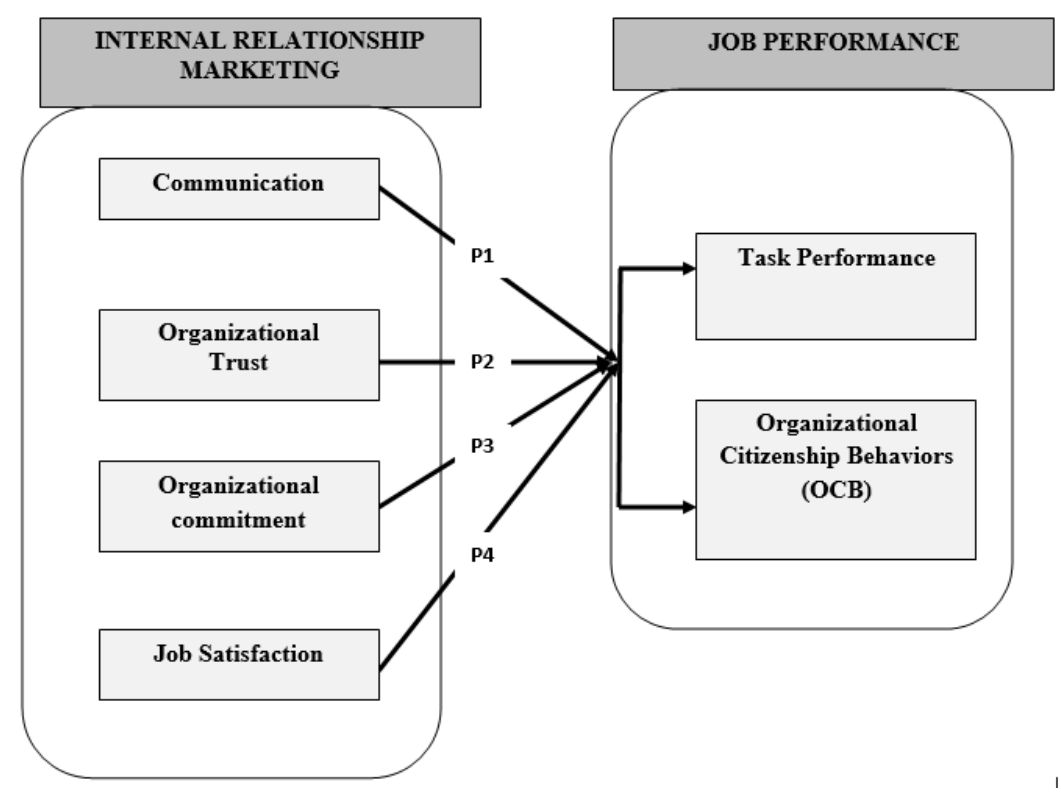

Figure 1. Conceptual model linking Internal Relationship Marketing to job Performance

\section{Research Contributions}

This paper has many contributions: First, our research contributes to the field of human resources, through the presentation of a mechanism for improving job performance. This mechanism is based on employee positive behaviors and attitudes such as: communication, organizational trust, organizational commitment and job satisfaction.

secondly, in marketing field, our research highlights the relevance and usefulness of IRM in improving job performance. In fact, instead of spreading resources on various practices to evaluate and improve a variety of attitudes, behaviors and motivation, it may be interesting for companies, to focus resources on IRM.

Third, in managerial practice, employee performance is generally assessed on the basis of objective criteria commonly grouped in task performance. In our model, in addition to objective criteria, employee job performance can be evaluated on the basis of subjective criteria such as OCBs.

Fourth, research on OCBs has placed limited emphasis on mechanisms of development of these behaviors. In this context, our research brings new knowledge to this field by highlighting their process of creation and growth.

Fifthly, our conceptual model contributes to research on employee-organization relationship, through the proposal of a win-win tool for developing such a relationship. For employee, IRM promotes a motivating work atmosphere and work enthusiasm which contributes to a good employee perception of the organizational relationship and organizational member interaction. On the company side, adopting IRM approach encourages employee to increase his job performance which has significant effects on financial and organizational performance of the company.

\section{Conclusion and Suggestions for Future Research}

In this work, we tried to establish from an analysis of the existing literature, the links between internal relationship marketing and job performance. IRM is seen as the process of establishing, maintaining and strengthening relationships between organization and employees. This process is based on relational determinants that ensure the sustainability of relationships, namely: communication, organizational trust, organizational commitment and job satisfaction.

The analysis of the literature review allowed us to show that the implementation of IRM favors the development of employees' job performance, specifically task performance and contextual performance (Organizational Citizenship Behaviors). Effective communication between company and its employees, as well as among 
employees themselves, promotes a climate of organizational trust and therefore the development of positive attitudes and behaviors including organizational commitment and job satisfaction. This process with its various components positively influences task performance and OCB.

Future research directions can be suggested including, the empirical validation of our research proposals. Conducting a quantitative study through an employee and leadership survey can be very helpful. In this context, it is proposed to carry out an empirical study in the service sector in which the participation of employees is one of the main characteristics of the service. Also, conducting qualitative studies will be important. This kind of study will help identify other factors and variables, besides IRM, that can improve employee job performance

\section{References}

Abbas R. A., \& Riaz, M. T. (2018). The effect of internal marketing dimensions on organizational commitment of employees: An Investigation among Private Banks in Faisalabad, Pakistan (A study based on different dimensions of internal marketing). European Online Journal of Natural and Social Sciences, 7(1), 147-165.

Adams, J. S. (1963) Toward an understanding of inequity. Journal of Abnormal and Social Psychology, 67, 422-436. https://doi.org/10.1037/h0040968

Ahmadi, S. A. A., Ahmadi, F., \& Zandieh, A. (2011). Social Capital and its Impact on Job Satisfaction. Interdisciplinary Journal of Contemporary Research in Business, 3(2), 460-478.

Ahmed, P. K., \& Rafiq, M. (1995). The Role of IM in the Implementation of Marketing Strategies. Journal of Marketing Practice: Applied Marketing Science, 1(4), 32-51. https://doi.org/10.1108/EUM0000000003891

Ahmed, P. K., \& Rafiq, M. (2002). Internal Marketing - Tools and concepts for customer focused management (1th ed.), Oxford : Butterworth-Heinemann Publications.

Ahmed, P. K., \& Rafiq, M. (2003). Internal marketing issues and challenges. European Journal of Marketing. 37(9). https://doi.org/10.1108/03090560310498813

Ahmed, P. K., \& Rafiq, M. (2004). Internal marketing: Tool and concepts for customer focused management (2nd ed.). Oxford: Butterworth-Heinemann.

Ahn, J., Lee, S., \& Yun, S. (2018). Leaders' Core Self-evaluation, Ethical Leadership, and Employees' Job Performance: The Moderating Role of Employees' Exchange Ideology. Journal of Business Ethics, 148, 457-470. https://doi.org/10.1007/s10551-016-3030-0

Anderson, J. C., \& Narus, J. A. (1990). A model of distributor firm and manufacturer firm working partnerships. Journal of Marketing, 54(1). https://doi.org/10.2307/1252172

Ang, S., Van Dyne, L., Koh, S. K., Ng, K. Y., Templer, K. J., Tay, C., \& Chandrasekar, N. A. (2007). Cultural intelligence: An individual difference with effects on cultural judgment and decision making, cultural adaptation, and task performance. Management and Organization Review, 3, 335-371. https://doi.org/10.1111/j.1740-8784.2007.00082.x

Bakhit, A. Z. S., \& Azmi, M. N. (2017). The Influence of Organizational Commitment on Omani Public Employees' Work Performance. International Review of Management and Marketing, 7(2), 151-160.

Ballantyne, D. (1997), Internal Networks for Internal Marketing, Journal of Marketing Management, 1(5), 343-366. https://doi.org/10.1080/0267257X.1997.9964479

Barzoki, A. S., \& Ghujali, T. (2013). Study the Relationship of Internal Marketing with Job Satisfaction, Organizational Commitment and Organizational Citizenship Behavior. International Journal of Academic Research in Business and Social Sciences, 3(3).

Bateman, T. S., \& Organ, D. W. (1983). Job satisfaction and the good soldier: The relationship between affect and employee citizenship. Academy of Management Journal, 26(4), 587-595.

Berry, L. G. Shostack, L., \& Gregory, D. U. (1983). Emerging Perspectives in Services Marketing, Chicago, IL: American Marketing Association.

Berry, L. L. (1984). The Employee as Customer, in Lovelock. C. (Ed.) Services Marketing. Boston, MA: Kent Publishing.

Berry, L. L., \& Parasuraman, A. (1991). Marketing service: Competing through quality. New York: The Free Press.

Blois (2003). B2B relationship a social construction of reality? a study of marks and spencer and one of its major supplier, Marketing Theory, 3(1), 79-95. 
Borman, W. C., \& Motowidlo, S. J. (1993). Expanding the criterion domain to include elements of contextual performance. In Schmitt N. \& Borman W. C. (Eds.), Personnel selection in organizations (p. 71-98), San Francisco: Jossey-Bass.

Brody, M. (1945), The Relationship between Effciency and Job Satisfaction,( Unpublished Master's Thesis). New York University, New York.

Caceres, R. C., \& Paparoidamis, N. G., (2007). Service quality, relationship satisfaction, trust, commitment and business-to-business loyalty. European Journal of Marketing, 41(7/8), 836-867. https://doi.org/10.1108/03090560710752429

Cahill, D. J. (1996a). Internal marketing: Your company's next stage of growth, New York: The Haworth Press.

Cahill, D. J. (1996b). The managerial implication of the learning organisation: A new tool for internal marketing. Journal of Service Marketing, 9(4), 43-51. https://doi.org/10.1108/08876049510094513

Campbell, J. P. (1990). Modeling the Performance Prediction Problem in Industrial and Organizational Psychology, in M. D. Dunnette and L. M. Hough (eds), Handbook of Industrial and Organizational Psychology. PaloAlto: Consulting Psychologists Press. 1 (687-732).

Campbell, J. P., Gasser M. D, \& Oswald, F. L. (1996). The substantive nature of job performance variability. In Murphy K.R. (Dir.), Individual differences and behavior in organizations (258-299) USA: Wiley-Blackwell.

Cano, C., \& Sams, D. (2009). The importance of an internal marketing orientation in social services, International Journal of Nonprofit and Voluntary Sector Marketing, 14(3), 285-295. https://doi.org/10.1002/nvsm.357

Carter L., \& Gray D., (2007). Relational competence, internal market orientation and employee performance. The Marketing Review, 7(4). https://doi.org/10.1362/146934707X251137

Chang, C. C., Tseng, K. H., \& Chen, C. W (2012). The Moderating Role of Online Community Participation in the Relationship Between Internal Marketing and Organizational Citizenship Behavior. Social Behavior and Personality, 40(10), 1725-1738. https://doi.org/10.2224/sbp.2012.40.10.1725

Charbonnier, A., Silva, C. A., \& Roussel, P. (2007). Vers une mesure de la performance contextuelle au travail de l'individu : étude exploratoire. XVIIIème congrès de l'AGRH, septembre, Universite de Fribourg.

Charles-Pauvers, B., Commeiras, N., Peyrat-Guillard, D., \& Roussel, P. (2007). La performance individuelle au travail et ses déterminants psychologiques, in Saint-Onge S. et Haines V. (Eds.). Gestion des Performances au travail, (97-150) Bruxelles : De Boeck.

Charles-Pauvers, B., Commeiras, N., Peyrat-Guillard, D., \& Roussel, P. (2006). Les déterminants psychologiques de la performance au travail : un bilan des connaissances et proposition de voies de recherche. Notes du LIRHE, ${ }^{\circ} 436$.

Chen, S. H., \& Liu, P. Y. (2012). Effects of internal marketing, organizational commitment, job involvement and job satisfaction on work performance: A study of the elderly care institutions in Taiwan. Marketing Review, 9(3), 277-301.

Coleman, V. I. et \& Borman, W. C. (2000). Investigating the underlying structure of the citizenship performance domain. Human Resource Management Review, 10(1). https://doi.org/10.1016/S1053-4822(99)00037-6

Colquitt, J. A. B. A. Scott, B. A., \& LePine, J. A. (2007), Trust, Trustworthiness, and Trust Propensity: A Meta-Analytic Test of Their Unique Relationships With Risk Taking and Job Performance. Journal of Applied Psychology, 92(4), 909-927. https://doi.org/10.1037/0021-9010.92.4.909

Cooper, J., \& Cronin, J. (2000). Internal Marketing: competitive strategy for the long-term care industry. Journal of Business Research, 48(3), 177-181. https://doi.org/10.1016/S0148-2963(98)00084-8

Coovert, M. D., Miller, E. E. P., \& Bennett, W. (2017), Assessing Trust and Effectiveness in Virtual Teams: Latent Growth Curve and Latent Change Score Models. Social Science, 6(87). https://doi.org/10.3390/socsci6030087

Costa, A. C. (2003). Work team trust and effectiveness. Personnel Review, 32(5), 605-622. https://doi.org/10.1108/00483480310488360

Cross, R., \& Cummings, J. N. (2004). Tie and network correlations of individual performance in knowledge-intensive work. Academy of Management Journal, 47, 928-937. 
Dalal, R. S., Lam, H., Weiss, H. M., Welch, E. R., \& Hulin, C. L. (2009). A within-person approach to work behavior and performance: concurrent and lagged citizenship counter productivity associations, and dynamic relationships with affect and overall job performance. Academy of Management Journal, 52(5). https://doi.org/10.5465/amj.2009.44636148

Darolia, C. R., Kumari, P., \& Darolia, S. (2010). Perceived organizational support, work motivation, and organizational commitment as determinants of job performance. Journal of the Indian Academy of Applied Psychology, 36(1), 69-78.

Davar, S. C., \& RanjuBala (2012). Relationship between Job Satisfaction \& Job Performance: a Meta-analysis. The Indian Journal of Industrial Relations, 48(2).

de Jong, B. A., \& Elfring, T. (2010). How Does Trust Affect the Performance of Ongoing Teams? The Mediating Role of Reflexivity, Monitoring and Effort. Academy of Management Journal, 53(3), 535-549. https://doi.org/10.5465/amj.2010.51468649

Dennis, J. C. (1995). The managerial implications of the learning organisation: A new tool for internal marketing. Journal of Service Marketing, 9(4).

Dirania, K. M., \& Kuchinke, K. P. (2011). Job satisfaction and organizational commitment: validating the Arabic satisfaction and commitment questionnaire (ASCQ), testing the correlations, and investigating the effects of demographic variables in the Lebanese banking sector. The International Journal of Human Resource Management, 22(5). https://doi.org/10.1080/09585192.2011.556801

Dirks, K. T., \& Ferrin, D. L. (2002) Trust in Leadership: Meta-Analytic Findings and Implications for Research and Practice, Journal of Applied Psychology, 87(4), 611-628. https://doi.org/10.1037/0021-9010.87.4.611

Dirks, K., \& Ferrin, D. (2001). The role of trust in organizational settings. Organization Science, 12, 450-467. https://doi.org/10.1287/orsc.12.4.450.10640

Dwyer, D., Schurr, P., \& Oh, S. (1987). Developing buyer-seller relationships. Journal of Marketing, 51(2). https://doi.org/10.2307/1251126

Edwards, B. D., Bell, S. T, Arthur, W., \& Decuir, A. D. (2008) Relationships between Facets of Job Satisfaction and Task and Contextual Performance, Applied Psychology: An International Review, 57(3), 441-465.

EL Alaoui, A. M. (2014) Responsabilité Ethique et Sociale des Entreprises et Performance des Employés dans le travail: Cas des Banques Commerciales Marocaines, (Unpublished doctoral dissertation). Mohammed V-University, Rabat, Morocco.

EL Alaoui, A. M., Chakor, A., \& Mdaghri, A. A. (2012). Ethics, Relationship Marketing and Corporate Performance: Theoretical Analysis through the Mediating Variables. International Business Research, 5(8), 68-84.

EL Alaoui, A. M., Chakor, A., Mdaghri, A. A., (2013). Corporate Ethical and Social Responsibility and Relationship Marketing: A Content Analysis of the Web sites of Moroccan Commercial Banks. International Journal of Business and Management, 8(3), 71-102.

Felfe, J., Yan, W., \& Six, B. (2008). The Impact of Individual Collectivism on Commitment and Its Influence on Organizational Citizenship Behaviour and Turnover in Three Countries. International Journal of Cross Cultural Management, 8(2), 211-237. https://doi.org/10.1177/1470595808091790

Femi, A. F. (2014). The Impact of Communication on Workers' Performance in Selected Organisations in Lagos State, Nigeria. Journal of Humanities And Social Science (IOSR - JHSS), 19(8), 75-82. https://doi.org/10.9790/0837-19827582

Flipo, J. P. (2000).Effectiveness implies leaving myths aside. in Varey, R.J., Lewis, B.R. (eds.), Internal marketing: directions for management (63-74), Routledge, London.

Freedman, S. M., \& Montanari, J. R. (1980). An Integrative Model of Managerial Reward Allocation. The Academy of Management Review, 5(3).

Fu, W., \& Deshpande, S. P. (2014). The Impact of Caring Climate, Job Satisfaction, and Organizational Commitment on Job Performance of Employees in a China's Insurance Company. Journal of Business ethics, 124, 339-349. https://doi.org/10.1007/s10551-013-1876-y

Gounaris, S. (2010). Internal-market orientation: a misconceived aspect of marketing theory. European Journal of Marketing, 44(2). https://doi.org/10.1108/03090561011079837 
Greenfield, A. C., Jr., Norman, C. S., \& Wier, B. (2008). The effect of ethical orientation and professional commitment on earnings management behavior. Journal of Business Ethics, 83, 419-434. https://doi.org/10.1007/s10551-007-9629-4

Gronroos, C. (1981). Internal marketing: an integral part of marketing theory .in Donnelly, J.H. and george, W.R. (Eds), Marketing of Services (236-238), Proceedings of the American Marketing Association, Services Marketing Conference, Chicago.

Gronroos, C. (2004). The Relationship Marketing Process: communication, interaction, dialogue, et value. Journal of Business and Industrial Marketing, 19(2). https://doi.org/10.1108/08858620410523981

Guest, D. E., \& Conway, N. (2002). Communicating the Psychological Contract: An Employer Perspective. Human Resource Management Journal, 12(2). https://doi.org/10.1111/j.1748-8583.2002.tb00062.x

Hales, C. (1994). Internal marketing as an approach to human resource management: a new perspective or a metaphor too far? Human Resource Management Journal, 5(1). https://doi.org/10.1111/j.1748-8583.1994.tb00359.x

Ivens, B. S., \& Mayrhofer, U. (2003). Les facteurs de réussite du marketing relationnel. Décisions Marketing, 31, 39-47.

Jamal, M. (2011). Job stress, job performance and organizational commitment in a multinational company: An empirical study in two countries. International Journal of Business and Social Science, 2(20), 20-29.

Jang, S. C., Hu, C., \& Bai, B. (2006). A Canonical Correlation Analysis of E-Relationship Marketing and Hotel Financial Performance. Tourism and Hospitality Research, 6(4), 241-250. https://doi.org/10.1057/palgrave.thr.6050024

Jaramillo, F., Mulki, J. P., \& Marshall, G. W. (2005). A meta-analysis of the relationship between organizational commitment and salesperson job performance: 25 years of research. Journal of Business Research, 58, 705-714. https://doi.org/10.1016/j.jbusres.2003.10.004

Javadein, S. R., Rayej, H., Estiri, M., \& Ghorbani, H. (2011). The role of internal marketing in creation of sustainable competitive advantages. Trends in Applied Sciences Research, 6(4), 364-374. https://doi.org/10.3923/tasr.2011.364.374

Johnson S. K., Holladay C. L., \& Quinones, M. A. (2009). Organizational Citizenship Behavior in Performance Evaluations: Distributive Justice or Injustice? Journal of Bussiness Psychology, 24, 409-418. https://doi.org/10.1007/s10869-009-9118-0

Joseph, W. B. (1996). Internal marketing builds service quality. Marketing Review, 16(1), 54-59.

Kelemen, M., \& Papasolomou-Doukakis, I. (2004). Can culture be changed? A study of internal marketing. The Service Industries Journal, 24(5), 121-135. https://doi.org/10.1080/0264206042000276874

Keller, S. B., Lynch, D. F., Ellinger, A. E., Ozment, J., \& Calantone, R. (2006). The impact of internal marketing efforts in distribution service operations. Journal of Business Logistics, 27(1). https://doi.org/10.1002/j.2158-1592.2006.tb00243.x

Leo, Y. M. Sin, Alan, C. B., Tse, Oliver, H. M., Yau, Jenny, S. Y., \& Lee, R. C. (2002) The effect of relationship marketing orientation on business performance in a service-oriented economy. Journal of Services Marketing, 16(7), 656-676. https://doi.org/10.1108/08876040210447360

Lings, I. N. (2004). Internal market orientation construct and consequences. Journal of Business Research, 57(4). https://doi.org/10.1016/S0148-2963(02)00274-6

Lings, I. N., \& Greenley, G. E. (2009). The impact of internal and external market orientations on firm performance. Journal of Strategic Marketing, 17(1), 41-53. https://doi.org/10.1080/09652540802619251

Locke, E. A. (1976). The nature and causes of job satisfaction in M Dunette, Handbook of industrial and organizational psychology (1297-1349). Chicago: Rand McNally College Publishing Company,

Mayer, R. C., Davis, J. H., \& Schoorman, F. D. (1995). An integrative model of organizational trust. Academy of Management Review, 20(3). https://doi.org/10.5465/amr.1995.9508080335

Meral, Y., Yaşlığlu, M., \& Semerciöz, F. (2016), Effects of Trust on Job Satisfaction and Mediatory Role of New Identification between Trust and Job Satisfaction in Mergers. International Journal of Managerial Studies and Research (IJMSR), 4(5), 54-67.

Meyer, J. P. et \& Allen, N. J. (1991). A Three-Component Conceptualization of Organizational Commitment . 
Human Resource Management Review, 1(1). https://doi.org/10.1016/1053-4822(91)90011-Z

Mishra, S. (2009) Internal Marketing- A Tool to Harness Employees' Power in Service Organizations in India. International Journal of Business and Management, 5(1). https://doi.org/10.5539/ijbm.v5n1p185

Mohiuddin, B. M. (2017). Impact of Market Orientation on Firm's Customer-based Performance: The Moderating Role of Employee Orientation. Academy of Marketing Conference.

Morgan, R. M., \& Hunt, S. D. (1994). The commitment-trust theory of relationship marketing. Journal of Marketing, 58(3). https://doi.org/10.2307/1252308

Motowidlo, S. J. (2000). Some basic issues related to contextual performance and organizational Citizenship behavior in human resource management. Human Resource Management Review, 10(1). https://doi.org/10.1016/S1053-4822(99)00042-X

Motowidlo, S. J. (2003), Job performance, in Handbook of Pyschology, Industrial and Organizational Psychology, (39-52) sous la direction de W.C Borman, D.R. Ilgen, R.J. Klimoski et I.B. Weiner, Hoboken, NJ: Wiley, 12.

Mulki, J. P., Jaramillo, F., \& Locander, W. B. (2006). Effects of ethical climate and supervisory trust on salesperson's job attitudes and intentions to quit. Journal of Personal Selling \& Sales Management, 26(1), 19-26. https://doi.org/10.2753/PSS0885-3134260102

Organ, D. W. (1988). Organizational citizenship behavior: The good soldier syndrome. Lexington, MA: Lexington Books.

Organ, D. W., Podsakoff, P. M., \& MacKenzie, S. B. (2006), Organizational Citizenship Behavior: Its Nature, Antecedents, and Consequences. Sage Publication.

Palmatier, R. W., Lisa, S., Kenneth, R. E., \& Todd, A. (2008). Achieving Relationship Marketing Effectiveness in Business-to-Business Exchanges. Journal of the Academy of Marketing Science, 36(2), 174-190. https://doi.org/10.1007/s11747-007-0078-5

Papasolomou, I., \& Vrontis, D. (2006). Using internal marketing to ignite the corporate brand: The case of the UK retail bank industry. The Journal of Brand Management, 14(1-2), 177-195. https://doi.org/10.1057/palgrave.bm.2550059

Poropat, A. E. (2002). New Models of Work Performance and Their Implications for Employment Relations. International Employment Relations Association, University of Technology, Sydney

Rafiq, M., \& Ahmed, P. K. (2000). Advances in the internal marketing concept: definition, synthesis and extension. Journal of Services Marketing, 14(6), 449-462. https://doi.org/10.1108/08876040010347589

Rich, B. L., Lepine, J. A., \& Crawford E. R. (2010) .Job engagement: antecedents and effects on Job performance. Academy of Management Journal, 53(3), 617-635. https://doi.org/10.5465/amj.2010.51468988

Roșca, V. I. (2017). Using Internal Marketing Communications to Improve HRM in Service-Based Sports Organizations. Review of International Comparative Management, 18(4).

Rotundo, M., \& Sackett, P. R. (2002). The relative importance of task, citizenship, and counterproductive performance to global ratings of job performance: a policy capturing approach. Journal of Applied Psychology, 87(1). https://doi.org/10.1037/0021-9010.87.1.66

Saknarong, A., Ooncharoen, N., \& Jadesadalug, V. (2013). The influences of internal marketing on service excellence of hotel businesses in Thailand. Journal of International Business \& Economics, 13(4). https://doi.org/10.18374/JIBE-13-4.5

Sasser, W. E., \& Arbeit, S. P. (1976). Selling Jobs in the Service Sector. Business Horizon, 61-62. https://doi.org/10.1016/0007-6813(76)90053-7

Sheth, J. (2000), Relationship marketing paradigm shift or shaft"? in Sheth J. and Parvatiyar, A. Handbook of relationship marketing (609-620.). Sage Publication, London,

Shiu, Y. M., \& Yu, T. W. (2010). Internal marketing, organisational culture, job satisfaction, and organisational performance in non-life insurance. The Service Industries Journal, 30(6), 793-809. https://doi.org/10.1080/02642060701849840

Sin, L. Y. M., Tse, A. C. B., Yau, O. H. M., Chow, R. P. M., Lee, J. S. Y., \& Lau, L. B. Y. (2005). Relationship marketing orientation: scale development and cross-cultural validation. Journal of Business Research, 58(2). 
https://doi.org/10.1016/S0148-2963(02)00493-9

Singh, U., \& Srivastava, K. B. L. (2016), Organizational Trust and Organizational Citizenship Behaviour. Global Business Review, 17(3), 594-609. https://doi.org/10.1177/0972150916630804

Theron, E., \& Terblanche, N.S. (2010). Dimensions of relationship marketing in business-tobusiness financial services. International Journal of Market Research, 52(3). https://doi.org/10.2501/S1470785310201326

Van Scotter, J. R., \& Motowidlo, S. J. (1996). Interpersonal facilitation and job dedication as separate facets of contextual performance. Journal of Applied Psychology, 81(5). https://doi.org/10.1037/0021-9010.81.5.525

Varey, R., \& Barbara, L. (1999). A broadened conception of internal marketing. European Journal of Marketing, 33(10). https://doi.org/10.1108/03090569910285869

Vroom, V. H. (1964), Work and Motivation, New York: Wiley.

Wang, J., \& Wong, C. K. (2011). Understanding organizational citizenship behavior from a cultural perspective: An empirical study within the context of hotels in Mainland China. International Journal of Hospitality Management, 30, 845-854. https://doi.org/10.1016/j.ijhm.2011.01.005

Whitener, E., Brodt, S., Korsgaard, A. et \& Werner, J. (1998). Managers as Initiators of Trust: An Exchange Relationship Framework for Understanding Managerial Trustworthy Behavior. Academy of Management Review, 23(3). https://doi.org/10.5465/amr.1998.926624

Williams, L. J., \& Anderson, S. E. (1991). Job satisfaction and organizational commitment as predictors of organizational citizenship and in-role behaviors. Journal of Management, 17(3). https://doi.org/10.1177/014920639101700305

Yao, Q., Chen, R., \& Cai, G. (2013). How internal marketing can cultivate psychological empowerment and enhance employee performance. Social behavior and personality, 41(4), 529-538. https://doi.org/10.2224/sbp.2013.41.4.529

Yildirim, O. (2014). The Impact of Organizational Communication on Organizational Citizenship Behavior: Research Findings. Procedia - Social and Behavioral Sciences, 150, 1095-1100. https://doi.org/10.1016/j.sbspro.2014.09.124

Yoon, H. M., \& Suh, J. (2003). Organizational citizenship behaviors and service quality as external effectiveness of contact employees. Journal of Business Research, 56(8), 597-611. https://doi.org/10.1016/S0148-2963(01)00290-9

Zboja J. J., \& Hartline, M. D. (2010). Activities to Enhance Cross-Selling Performance in Services. Journal of Relationship Marketing, 9(3). https://doi.org/10.1080/15332667.2010.502004

Zeffane, R., Tipu, S., \& Ryan, J. (2011). Commitment, Communication \& Trust - Exploring the Triad. International Journal of Business and Management, 6(6), 77-87. https://doi.org/10.5539/ijbm.v6n6p77

Zhang, Y., \& Huai, M. Y. (2016). Diverse Work Groups and Employee Performance: The Role of Communication Ties. Small Group Research, 47(1), 28-57. https://doi.org/10.1177/1046496415604742

\section{Copyrights}

Copyright for this article is retained by the author(s), with first publication rights granted to the journal.

This is an open-access article distributed under the terms and conditions of the Creative Commons Attribution license (http://creativecommons.org/licenses/by/4.0/). 